DOI: $10.19195 / 0524-4544.326 .7$

\author{
MARCIN MIEMIEC \\ ORCID: 0000-0002-9100-0895 \\ Uniwersytet Wrocławski
}

\title{
Status ochotniczych straży pożarnych w Niemczech
}

\section{I}

Według niemieckiej normy DIN 14011 przez straż pożarną należy rozumieć organizację społecznie użyteczną, służącą pomocą bliźniemu (człowiekowi) w przypadku pożaru, zjawisk przyrody stwarzających zagrożenia o charakterze publicznym i w innych nieszczęśliwych wypadkach, w sytuacjach zagrażających życiu ludzi i zwierząt, w krytycznych sytuacjach na drogach, torach, w statkach powietrznych i wodnych, działającą także w zakresie prewencji pożarowej itp. ${ }^{1}$

W definicji wskazany został zakres zadań straży pożarnych. Punktem wyjścia była jednak ochrona przeciwpożarowa, która ma długą historię na obszarze Niemiec. Istniała bowiem $\mathrm{w}$ niemieckich miastach $\mathrm{w}$ zorganizowanych formach od końca średniowiecza. W związku z używaniem drewna jako materiału konstrukcyjnego obiektów budowlanych pożary stanowiły zagrożenie nie tylko dla poszczególnych nieruchomości, lecz często także dla całych miast. Nie było wówczas ubezpieczeń pożarowych, dlatego skutki ekonomiczne pożarów były bardzo dotkliwe dla poszkodowanych. Prawo miejskie nakładało więc na pewne kategorie obywateli - na przykład rzemieślników budowlanych — obowiązek udziału w ochronie przeciwpożarowej ${ }^{2}$. Były to początki prawa ochrony przeciwpożarowej. Określało ono również wymogi pożarowe stawiane budynkom, co uważa się za początki prawa budowlanego. Ochrona przeciwpożarowa miała dla

\footnotetext{
${ }^{1}$ W.-D. Prendke et al., Feuerwehr, [hasło w:] Lexikon der Feuerwehr, Kohlhammer 1999.

${ }^{2}$ E. Fleck, Turner standen an den Wiegen der freiwilligen Feuerwehren, [w:] H.-G. Kernmayr, Der goldene Helm, München 1956, s. 21.
} 
wyznaczonych osób charakter obowiązkowy i była wykonywana w formach określanych niekiedy jako pospolite ruszenie ${ }^{3}$.

Ochotnicze straże pożarne w Niemczech zaczęto organizować od 1840 roku. Większość z nich utworzono w drugiej połowie XIX wieku. Wzorem dla ówczesnych rozwiązań było francuskie pożarnictwo, które już w pierwszej połowie XIX wieku osiągnęło wysoki poziom. Za jego początek uznaje się powstanie zakładu pożarniczego Dumourrier-Duperrier, założonego w Paryżu w 1705 roku. Dekretem z 1811 roku przekształcono go w zorganizowany na wzór wojskowy batalion Sapeur-Pompier. Istotą tego rozwiązania była dobrowolność wstępowania do straży, wojskowe zasady jej organizacji i nieodpłatne, społeczne uczestnictwo. Dekret obowiązywał tylko w Paryżu, dlatego prefekci francuscy wydawali podobne regulacje, na przykład dla miasta Metz w 1812 roku. Tak zorganizowane straże pożarne w 1821 roku włączono do armii francuskiej, a w 1831 roku do Gwardii Narodowej jako samodzielny rodzaj wojsk. W 1845 roku ówczesny dowódca francuskiej straży pożarnej opracował podręcznik pożarnictwa, wielokrotnie aktualizowany, przetłumaczony na język niemiecki. W znaczny sposób wpłynął on na organizację pożarnictwa niemieckiego 4 .

Niektóre regulacje francuskie, w szczególności dotyczące struktury wojskowej, wyposażenia w sprzęt gaśniczy, umundurowania strażaków, przyjęto zatem $\mathrm{w}$ procesie tworzenia pierwszych straży pożarnych w południowo-zachodnich Niemczech. Korzystano również z francuskich nazw, jak na przykład Pompier Corps Durlach. W Niemczech za najstarsze uznaje się kilka ochotniczych straży pożarnych, w szczególności straż pożarną w Saarlouis, utworzoną w 1811 roku na podstawie uchwały magistratu miasta, za zezwoleniem prefekta Metzu, przez przekształcenie dotychczas istniejącej straży pożarnej ${ }^{5}$.

W latach rewolucji mieszczańskiej (1848-1849) pierwsze ochotnicze straże pożarne, wyłonione $\mathrm{z}$ istniejących od początku XIX wieku zrzeszeń gimnastycznych $^{6}$, włączono jako samodzielne jednostki do milicji obywatelskich. Po upadku rewolucji wielu komendantów tych straży skazano za zdradę stanu na kary więzienia. Straże pożarne jednak zachowano. Nikt nie podważał konieczności ich istnienia. Miały na to wpływ duże pożary, na przykład w dniach 5-8 maja 1842 roku, gdy w wyniku jednego z nich zniszczone zostały dwie trzecie Hamburga. Istotne znaczenie miał także pożar teatru w Karlsruhe 28 lutego 1847 roku. Gdy służbom gaśniczym miasta nie udało się sprostać zadaniu, na pomoc wezwano Pompier

${ }^{3}$ F. Wolter, Die freiwilligen Feuerwehren in Österreich und Deutschland, Wiesbaden 2011, s. $38-39$.

${ }^{4}$ Ibidem, s. 43 n.

${ }^{5}$ D. Jarausch, Feuerwehren. Wie sind sie entschtanden?, s. 3 n., https://www.vfdb.de/fileadmin/abdownloads/Vortrag_CTIF-AG-Feuerwehrhistorik_10_2009_07_03_2009.doc.pdf (dostęp: 10.07.2018).

${ }^{6}$ F. Wolter, op. cit., s. 43-44. Zrzeszenia te były tworzone na początku XIX wieku jako struktury przeciwstawiające się dominacji napoleońskiej w Niemczech. 
Corps Durlach, który ugasił pożar. O ile przykład Hamburga wskazał, jak duże szkody może wywołać pożar, to przykład Karlsruhe dowiódł, jak można go skutecznie zwalczyć. W następnych latach delegacje z całych Niemiec wizytowały Durlacher Pompier Corps, aby poznać jego organizację. Od 1855 do 1876 roku powstało wiele ochotniczych straży pożarnych, na przykład w Bawarii, Wirtembergii, Badenii i Saksonii było ich łącznie 5734. Ich cechami charakterystycznymi były: trwała organizacja skierowana na zwalczanie pożarów, w której istniał ustalony podział pracy i usytuowanie w hierarchii poszczególnych jej członków, stosowne wyposażenie, obowiązek uczestnictwa w zebraniach, w ćwiczeniach oraz dobrowolność wstępowania i uczestnictwa wszystkich członków ${ }^{7}$.

Po utworzeniu ochotniczych straży pożarnych w celu wymiany doświadczeń zaczęto dążyć do zakładania ich związków na poziomie powiatowym i krajowym, w Prusach także prowincjonalnym ${ }^{8}$. W czerwcu 1853 roku utworzono Związek Niemieckich Straży Pożarnych jako organizację dachową zorganizowaną w formie stowarzyszenia zarejestrowanego 9 .

Do początku lat 30 . XX wieku regulacja prawna straży pożarnych była rozproszona, zawarta w rozporządzeniach policyjnych i w regulaminach gaśniczych. Zmieniła to pruska ustawa z 15 grudnia 1933 roku o gaśnictwie pożarowym, wprowadzając po raz pierwszy w całym kraju związkowym regulację organizacji straży pożarnych, ich zrzeszeń, nadzoru i postępowania w przypadku pożaru. Ustawa podporządkowała straże pożarne lokalnemu komendantowi policji i nadzorowi policyjnemu. 23 listopada 1938 roku uchwalono wzorowaną na pruskiej ustawę rządową o gaśnictwie pożarowym, obowiązującą w całej III Rzeszy ${ }^{10}$. Na jej mocy zawodowe straże pożarne włączono jako służby techniczne do policji i nazwano je ochronną policją pożarową. Związki ochotniczych straży pożarnych rozwiązano, a straże ochotnicze nazwano pomocniczą ochronną policją pożarową. Całą kadrę kierowniczą pożarnictwa zweryfikowano politycznie, a przeciwników władzy nazistowskiej usunięto. Wraz z wybuchem wojny wielu strażaków, szczególnie ochotniczych, wcielono do armii. Przyjęte w III Rzeszy usytuowanie straży pożarnych było kontynuowane po wojnie w radzieckiej strefie okupacyjnej, a następnie w Niemieckiej Republice Demokratycznej, w ustawach z 1949 roku i z 1956 roku $^{11}$.

Jednym z pierwszych rozstrzygnięć władz okupacyjnych w zachodnich sektorach było natomiast oddzielenie straży pożarnych od policji ${ }^{12}$. Związek Niemieckich Straży Pożarnych reaktywowano 12 stycznia 1952 roku w Fuldzie. Obecnie

${ }^{7}$ D. Leupold, Die freiwilligen Feuerwehren in der Rheinprovinz bis 1918, Köln 2003, s. 17-18.

8 Ibidem.

${ }^{9}$ http://www.feuerwehrverband.de/geschichte.html (dostęp: 10.07.2018).

${ }^{10}$ P. Richter, Historische Rechtsgrundlagen für die Feuerwehren auf dem Gebiet des Landes Brandenburg, „Beiträge zur Feuerwehrgeschichte”, z. 4, s. 2.

${ }^{11}$ Ibidem.

12 Zob. F.-L. Knemeyer, Polizei- und Ordnungsrecht, München 1995, s. 6-7. 
zrzesza on 16 krajowych związków straży pożarnych, grupy federalne zawodowych i zakładowych straży pożarnych. Zgodnie ze statutem związek reprezentuje interesy całego niemieckiego pożarnictwa na płaszczyźnie krajowej, europejskiej i międzynarodowej, wspiera straże pożarne w ich działaniach ochronnych i prewencyjnych przed zagrożeniami, działa na rzecz przygotowania wiarygodnego, ochronnego i prewencyjnego systemu pomocy w zagrożeniach w Niemczech oraz tworzy sieć powiązań o charakterze spajającym i informacyjnym wobec jego członków ${ }^{13}$.

Krajowe związki straży pożarnych są stowarzyszeniami zarejestrowanymi. Zrzeszają powiatowe ${ }^{14}$, miejskie, okręgowe związki straży pożarnych oraz krajowe związki zawodowych i zakładowych straży pożarnych. Związki reprezentują interesy ich członków, promują pożarnictwo, prowadzą działalność wychowawczą i uświadamiającą w zakresie ochrony przeciwpożarowej, wspierają rozwój pożarnictwa, ochrony przeciwpożarowej i ochrony przed katastrofami, kształcenie i dokształcanie strażaków, upowszechnianie muzyki strażackiej, wspierają młodzieżowe i dziecięce straże pożarne.

\section{II}

W Niemczech straże pożarne dzielą się na publiczne i niepubliczne. Publicznymi są straże pożarne tworzone przez gminy w celu zabezpieczenia ochrony przeciwpożarowej i świadczenia ogólnej pomocy, czyli zawodowe ${ }^{15}$, ochotnicze i obowiązkowe straże pożarne. Niepublicznymi strażami pożarnymi są straże zakładowe i fabryczne, powoływane dla zabezpieczenia ochrony przeciwpożarowej i świadczenia ogólnej pomocy w sytuacji zagrożeń. Straże pożarne zawodowe są obligatoryjnie tworzone w niemieckich miastach liczących 80 tys. i więcej mieszkańców oraz w miastach o dużym zagrożeniu pożarowym. W pozostałych miastach ich tworzenie jest fakultatywne. W 2016 roku w Niemczech istniało 107 zawodowych straży pożarnych ${ }^{16}$.

Ochotnicze straże pożarne stanowią współcześnie podstawę systemu ochrony przeciwpożarowej w Niemczech. Na dzień 31 grudnia 2015 roku w 22690 ochotniczych strażach pożarnych było zrzeszonych 996688 osób ${ }^{17}$. Poza nielicznymi

$13 \mathrm{http}: / /$ www.feuerwehrverband.de/ordentliche-mitglieder.html?\&L=0Sebastian (dostęp: 10.07.2018).

${ }^{14}$ W Krajowym Związku Straży Pożarnych Saksonii jest obecnie zrzeszonych 17 powiatowych i miejskich związków straży pożarnych, zob. https://www.lfv-sachsen.de/wir-ueber-uns/stadt-kreisfeuerwehrverbaende (dostęp: 10.07.2018).

15 Pierwsza niemiecka zawodowa straż pożarna powstała w 1851 roku w Berlinie.

16 Berufsfeuerwehren in Deutschland - Komplettes Adressverzeichnis, Feuerwehr-Magazin, Ebner Verlag 2016.

${ }^{17}$ Deutscher Feuerwehrverband. Statistik, http://www.feuerwehrverband.de/statistik.html (dostęp: 10.07.2018). 
gminami z obowiązkowymi strażami pożarnymi ${ }^{18} \mathrm{w}$ gminach bez zawodowych straży pożarnych zadania gmin w zakresie ochrony przeciwpożarowej wykonują wyłącznie ochotnicze straże pożarne. W miastach, w których istnieją zawodowe straże pożarne, są one wspierane przez ochotnicze straże pożarne.

Członkowie ochotniczych straży pożarnych wykonują zadania społecznie, nieodpłatnie. W nielicznych gminach niemieckich korzystają z pewnych udogodnień w dostępie do usług komunalnych lub otrzymują niewielkie wsparcie finansowe. Nie jest to jednak ekwiwalentne, adekwatne do nakładu świadczonej pracy na rzecz straży pożarnej. W ustawowo określonych sytuacjach (liczba mieszkańców gminy, stopień zagrożenia pożarowego) strażacy ochotnicy są wspierani przez etatowy personel fachowy.

\section{III}

Ochrona przeciwpożarowa należy do zakresu zadań administracji publicznej. Zgodnie z art. 30 konstytucji federalnej ${ }^{19}$ wykonywanie kompetencji i zadań państwowych należy do krajów związkowych, jeśli konstytucja nie zawiera lub nie dopuszcza innej regulacji. Według art. 70 kraje związkowe mają władzę ustawodawczą, o ile konstytucja nie powierza jej federacji. Przepisy te ustanawiają domniemanie właściwości krajów związkowych w sprawach z zakresu władzy wykonawczej, której częścią jest administracja publiczna. W rozpatrywanym zakresie chodzi więc o materię ochrony przeciwpożarowej zastrzeżoną dla regulacji w ustawach krajowych i w aktach wykonawczych do tych ustaw, a także o wykonywanie administracji publicznej z tego zakresu.

W związku z tym prawo ochrony przeciwpożarowej jest w każdym kraju związkowym uregulowane odrębną ustawą. Ustawy te są w swej konstrukcji i treści podobne do siebie. Przykładowo zostanie scharakteryzowana ustawa Wolnego Państwa (kraju związkowego) Saksonia graniczącego z województwem dolnośląskim, które współpracuje z Saksonią w ramach różnych formach organizacyjnych i funkcjonalnych, także na poziomie gmin i powiatów ${ }^{20}$.

18 W 2017 roku w Niemczech były cztery takie straże pożarne, zob. https://de.wikipedia.org/ wiki/Pflichtfeuerwehr (dostęp: 10.07.2018).

19 Grundgesetz für die Bundesrepublik Deutschland vom 23. Mai 1949 (BGBl, s. 1).

20 Zob. np. Program Współpracy INTERREG Polska-Saksonia 2014-2020 — projekty i plan naborów w 2018 r., https://www.cpe.gov.pl/aktualnosci/szczegoly/696,program-wspolpracy-interregpolska-saksonia-2014-2020-nowe-projekty-oraz-plan-naborow-w-2018-r (dostęp: 10.07.2018). 


\section{IV}

Saksońska ustawa z dnia 24 czerwca 2004 roku w sprawie ochrony przeciwpożarowej, służby ratowniczej i ochrony przed katastrofami ${ }^{21}$ reguluje kompleksowo trzy obszary aktywności administracji publicznej wymienione w jej tytule, które mieszczą się także w zakresie zadań ochotniczej straży pożarnej22 ${ }^{22}$ Zakres regulacji ustawy obejmuje następujące kwestie: zadania i ich wykonawców, współdziałanie, ochronę przeciwpożarową, służby ratownicze, ochronę przed katastrofami, organizację kierowania, uświadamiania, samopomocy społeczeństwa w stanach kryzysowych, obowiązek współdziałania, odszkodowania, społecznych (niezawodowych) członków ochotniczych straży pożarnych, kosztów funkcjonowania ustawy, ochrony danych osobowych, wykroczeń będących następstwem naruszenia przepisów ustawy.

Celem ustawy jest stworzenie systemu zapewniającego ochronę społeczeństwa w zakresie objętym jej regulacją, z pewnymi wyłączeniami. Nie obejmuje na przykład służb ochronnych policji, sądownictwa, kolei i gazownictwa, lotnictwa, transportu sanitarnego. Ustawa definiuje takie pojęcia, jak: ochrona przeciwpożarowa, służba ratunkowa, ochrona przed katastrofami, jednostka zlecająca i kierująca służbami ratunkowymi.

Podmiotami odpowiedzialnymi za wykonywanie zadań są gminy odnośnie do miejscowej ochrony przeciwpożarowej, powiaty ziemskie odnośnie do ponadmiejscowej, komunalne celowe związki ratunkowe dla terytorialnych służb ratowniczych, a także powiaty i miasta wyłączone z powiatów, niezrzeszone w związkach celowych. W zakresie centralnych spraw ochrony i lotniczej służby ratunkowej właściwy jest kraj związkowy Saksonia. W sprawach ochrony przeciwpożarowej, służb ratunkowych i ochrony przed katastrofami władzą najwyższą jest krajowe ministerstwo spraw wewnętrznych, władzą wyższą — krajowa dyrekcja Saksonii, władzą niższą — powiaty ziemskie i miasta wyłączone z powiatów. W zakresie ochrony przeciwpożarowej władzą lokalną są gminy.

Zadania jednostek samorządu terytorialnego w zakresie jej regulacji mają charakter obowiązkowy. Ustawa określa organy sprawujące nadzór i jego charakter. Z uwagi na przedmiot niniejszego opracowania dalsze wywody będą skupione na problematyce ochotniczych straży pożarnych.

Gminy określane jako lokalne władze ochrony przeciwpożarowej są obowiązane do ustanowienia, wyposażenia, utrzymywania i zapewnienia zdolności

${ }^{21}$ Sächsisches Gesetz über den Brandschutz, Rettungsdienst und Katastrophenschutz (SächsBRKG) erlassen als Artikel 1 des Gesetzes zur Neuordnung des Brandschutzes, Rettungsdienstes und Katastrophenschutzes im Freistaat Sachsen. Vom 24. Juni 2004 (SächsGVBl, nr. 9, s. 245, 647).

${ }^{22} \mathrm{~W}$ części krajów związkowych kwestie organizacji i funkcjonowania samego pożarnictwa regulują odrębne ustawy, zob. https://de.wikipedia.org/wiki/Feuerwehrgesetz_(Deutschland) (dostęp: 10.07.2018) 
do działania odpowiadającej stosunkom miejscowym publicznej straży pożarnej, zgodnie z planem zapotrzebowania na ochronę przeciwpożarową, wraz z wymaganymi obiektami budowlanymi, urządzeniami i wyposażeniem, wyszkoleniem, dokształcaniem członków publicznych straży pożarnych, zabezpieczeniem systemu alarmowego publicznej straży pożarnej, zabezpieczeniem odpowiednio do stosunków miejscowych wystarczającego dostępu do wody gaśniczej; opracowania, aktualizacji i — jeśli to jest konieczne — uzgodnienia regulaminów alarmowych i ewakuacyjnych, jak również planów interwencji; udzielania na czas niezbędnych informacji oraz przekazywania niezbędnych dokumentów regulujących interwencję ośrodkom kierowniczym; wspierania wychowania w zakresie ochrony przeciwpożarowej; przeprowadzania pokazów w zakresie prewencji przeciwpożarowej; sporządzania zbiorczych sprawozdań z interwencji ich publicznej straży pożarnej; zbierania danych statystycznych w zakresie wyposażenia osobowego i technicznego, interwencji.

Ochotnicze, zawodowe i obowiązkowe straże pożarne jako jednostki organizacyjne gminy są publicznymi strażami pożarnymi nieposiadającymi osobowości prawnej. Zakładowe i fabryczne straże pożarne są prywatnoprawnie zorganizowanymi strażami pożarnymi, służącymi ochronie przedsiębiorstw i ich urządzeń (instalacji).

W każdej gminie powinna istnieć ochotnicza straż pożarna. W gminach liczących powyżej 80 tys. mieszkańców tworzona jest zawodowa straż pożarna, która wraz z ochotniczą strażą pożarną stanowi gminną straż pożarną. W gminach podzielonych na miejscowości poszczególne straże pożarne wchodzą w skład gminnej straży pożarnej. Noszą nazwę gminy i mogą do niej dodać nazwę miejscowości, w której mają siedzibę. Prawa i obowiązki członków straży pożarnej, o ile to nie wynika $z$ ustawy, są uregulowane w uchwale rady gminy (statucie).

Publiczne straże pożarne uczestniczą w wykonywaniu zadań gminy z zakresu ochrony przeciwpożarowej. W zwalczaniu skutków katastrof oraz w służbie ratunkowej i w usuwaniu zagrożeń środowiska świadczą pomoc techniczną. Przepisy szczególne mogą nakładać inne zadania na publiczne straże pożarne. Podczas zwalczania pożaru i świadczenia pomocy technicznej straże powinny stosować dopuszczalne ustawowo środki, jeżeli to jest niezbędne do likwidacji niebezpieczeństwa lub zmniejszenia zagrożenia.

Gminną strażą pożarną dowodzi jej kierownik. Straże pożarne w poszczególnych miejscowościach gminy są zarządzane przez ich kierowników. Kierownicy i ich zastępcy są wybierani na podstawie statutu i powoływani na pięć lat. Kandydaci muszą być osobowo i fachowo przygotowani do pełnienia tych funkcji. Z ważnych przyczyn mogą być odwołani przez gminę przed upływem kadencji. Kierownik gminnej straży pożarnej jest odpowiedzialny za zdolność straży do działania i prawidłowe wykonywanie obowiązków gminnej straży pożarnej. Jest obowiązany do świadczenia doradztwa we wszystkich technicznych sprawach pożarniczych i ochrony przeciwpożarowej. 
Ogólnie członkowie ochotniczych straży pożarnych działają społecznie. Niezbędni etatowi członkowie ochotniczych straży pożarnych są zatrudniani i szkoleni na zasadach obowiązujących w zawodowych strażach pożarnych. Aktywni członkowie ochotniczych straży pożarnych są obowiązani także do uczestnictwa w służbowych przedsięwzięciach mających na celu szkolenie i dokształcanie ${ }^{23}$.

Do aktywnej służby pożarniczej mogą być przyjmowane osoby, które ukończyły 16 lat, spełniają wymogi zdrowotne służby pożarniczej i mają odpowiednie cechy charakteru. Służbę pożarniczą w gminach mogą pełnić wszystkie osoby, które tam zamieszkują albo są tam na stałe zatrudnione, pobierają naukę czy w inny sposób pozostają do dyspozycji straży w sytuacjach wymagających interwencji. Członkowie pełniący funkcje kierownicze i ich zastępcy powinni mieć w gminie pierwsze miejsce zamieszkania. Służba pożarnicza może być pełniona w nie więcej niż dwóch jednostkach straży pożarnej.Interesy straży pożarnej gminy, w której członek straży mieszka czy przeważnie mieszka, powinny być uwzględniane w pierwszej kolejności.

Podania o przyjęcie do straży pożarnej powinny być składane na piśmie do kierownika miejscowej straży pożarnej. O przyjęciu rozstrzyga kierownik straży gminnej. Nie ma roszczenia prawnego o przyjęcie do straży. Odmowa przyjęcia jest dokonywana w formie pisemnego aktu administracyjnego. Jeśli aktywny członek straży nie spełnia już warunków uczestnictwa w straży, należy go zwolnić ze służby.

Niezdolne do służby w ochotniczej straży pożarnej są osoby niemające zgodnie z wyrokiem sądu — zdolności do pełnienia urzędów publicznych, poddane środkom poprawczym lub zabezpieczającym stosownie do $\S 61$ kodeksu karnego (poza pozbawieniem prawa jazdy), a także pozostający pod opieką czy przejściową kuratelą.

W ramach ochotniczych straży pożarnych mogą być tworzone młodzieżowe straże pożarne zrzeszające osoby, które ukończyły 8 lat, a także działy strażaków — seniorów, osób zasłużonych dla straży pożarnej lub inne komórki organizacyjne.

W gminach, w których istnieje zawodowa straż pożarna, jej kierownik wykonuje funkcję gminnego kierownika straży pożarnej i jest odpowiedzialny za zdolność do działania wszystkich straży pożarnych w gminie.

Gmina powinna powołać obowiązkową straż pożarną, jeśli nie uda się utworzyć ochotniczej straży pożarnej. Do zapewnienia minimalnej zdolności działania ochotniczej straży pożarnej poszczególni mieszkańcy i urzędnicy gminni zdolni do jej pełnienia mogą być zobowiązani do służby. Do tej kategorii należą osoby między 18 a 65 rokiem życia. Kto zamieszkuje w większej liczbie gmin w RFN, jest zdolny do służby pożarniczej tylko w gminie, w której ma główne mieszka-

${ }^{23}$ W każdym kraju związkowym w Niemczech istnieje co najmniej jedna krajowa szkoła pożarnicza, której głównym zadaniem jest szkolenie i doskonalenie strażaków, zob. http://deacademic. com/dic.nsf/dewiki/2462702 (dostęp: 10.07.2018). 
nie. Do służby niezdolna jest osoba niespełniająca wymogów zdrowotnych służby pożarniczej, a także osoba, która wskaże ważny powód w rozumieniu $\S 18$ ust. 1 zd. 1 i zd. 2 pkt 3-5 saksońskiej ordynacji gminnej ${ }^{24}$. Gmina w formie decyzji zobowiązującej włącza do służby pożarniczej osobę zdolną do jej pełnienia. Do obowiązkowych straży pożarnych stosowane są odpowiednio przepisy o ochotniczych strażach pożarnych.

Społecznie czynni członkowie ochotniczych straży pożarnych są obowiązani do udziału w interwencjach, ćwiczeniach, szkoleniach i dokształcaniu członków ochotniczej straży pożarnej, do której należą. Powinni oni być na czas wzywani do udziału w zaplanowanych ćwiczeniach, szkoleniu czy dokształcaniu, które powinny odbywać się poza czasem pracy, jednak w wymiarze nie mniejszym niż 40 godzin rocznie.

Społecznie czynni członkowie ochotniczych straży pożarnych nie powinni być z uwagi na ich służbę narażeni na uszczerbek w ramach stosunku pracy czy stosunku służbowego. W szczególności niedopuszczalne jest wypowiedzenie im stosunku pracy, stosunku służbowego, zwolnienie czy inne ograniczenie zawodowe z powodu ich działalności w ochotniczej straży pożarnej.

Jeżeli społecznie czynni członkowie ochotniczych straży pożarnych biorą udział w interwencjach, ćwiczeniach, szkoleniach i dokształcaniu, powinni być w tym czasie, a także w niezbędnym czasie po tych czynnościach, zwolnieni z czynności zawodowych (służbowych). Osoby zatrudnione w służbie publicznej korzystają z takich uprawnień, o ile nie sprzeciwia się temu nadrzędny interes publiczny. O udziale w szkoleniach czy dokształcaniu należy na czas powiadomić prywatnego lub publicznego pracodawcę.

Pracodawca jest obowiązany wypłacać członkom ochotniczej straży pożarnej za czas interwencji, ćwiczeń, szkoleń i dokształcania wynagrodzenie lub uposażenie łącznie ze świadczeniami dodatkowymi i dodatkami, które uzyskaliby oni, gdyby w tym czasie nie uczestniczyli we wskazanych działaniach. Dotyczy to także ustawowo należnej kontynuacji wypłaty w przypadku niezdolności do pracy spowodowanej działalnością w ochotniczej straży pożarnej. Prywatny pracodawca może na wniosek uzyskać rekompensatę od gminy z tytułu poniesionych kosztów wskazanych wynagrodzeń.

Społecznie czynnemu członkowi ochotniczej straży pożarnej niebędącemu pracobiorcą przysługuje na jego wniosek rekompensata z tytułu utraty zarobku za czas interwencji, ćwiczeń, szkoleń czy dokształcania. Maksymalne kwoty przysługujące z tego tytułu może określić najwyższy organ kraju związkowego w zakresie ochrony przeciwpożarowej.

24 Gemeindeordnung für den Freistaat Sachsen (SächsGemO) vom 21. April 1993 (SächsGVB1, s. 301). Przepis ten stanowi, że rada gminy może w formie statutu (aktu prawa miejscowego) ustalić, że radnym gminy, radnym jednostek wewnętrznych gminy (wsi, osiedli), członkom komisji rady gminy, doradcom rady gminy i rad jednostek wewnętrznych gminy przysługuje zwrot nakładów za czas poświęcony wykonywaniu ich funkcji. 
Społecznie czynni członkowie ochotniczej straży pożarnej na wniosek otrzymują od gminy zwrot nakładów poniesionych z tytułu wykonywania służby, a także z tytułu udziału w szkoleniach i dokształcaniu. Kierownicy ochotniczych straży pożarnych, ich zastępcy i inne osoby pełniące służbę przeciwpożarową, których aktywność regularnie przekracza przeciętną miarę zaangażowania przyjętą $\mathrm{w}$ ochotniczej straży pożarnej, otrzymują zwrot poniesionych nakładów. Inni członkowie ochotniczej straży pożarnej mogą otrzymywać zwrot takich nakładów. W tym zakresie stosuje się odpowiednio $§ 21$ ust. 2 i 4 saksońskiej ordynacji gminnej. Najwyższy organ w zakresie pożarnictwa jest właściwy do ustalenia w drodze rozporządzenia maksymalnych stawek zwrotu nakładów na rzecz członków ochotniczych straży pożarnych, a także wymogów i wysokości świadczeń z tytułu jubileuszu świadczenia służby na rzecz społecznie czynnych członków ochotniczych straży pożarnych.

Szkody majątkowe powstałe u społecznie czynnych członków ochotniczej straży pożarnej w toku wykonywania bądź na skutek wykonywania służby, łącznie ze szkoleniem czy dokształcaniem, są rekompensowane przez gminę, jeżeli nie mają oni innego roszczenia odszkodowawczego, chyba że osoby te spowodowały szkodę umyślnie lub na skutek rażącej niedbałości. Dotyczy to także konsekwencji ubezpieczeniowych szkód majątkowych, które ponieśli społecznie czynni członkowie ochotniczych straży pożarnych jako właściciele lub użytkownicy pojazdów mechanicznych, a także pojazdów mechanicznych innych osób, użytych w czasie interwencji.

Społecznie czynnym członkom ochotniczej straży pożarnej, którzy w wyniku akcji doznali szczególnego obciążenia psychicznego, należy zapewnić terapię psychologiczną.

Interwencje gminnej straży pożarnej w zakresie zwalczania pożarów i świadczenia pomocy technicznej są w zasadzie nieodpłatne, chyba że ustawa stanowi inaczej. Do pokrycia kosztów poniesionych przez gminę jest zobowiązany: sprawca, jeżeli niebezpieczeństwo bądź szkoda powstały na skutek jego umyślnego działania bądź rażącego niedbalstwa; posiadacz pojazdu mechanicznego, szynowego, powietrznego lub wodnego, jeżeli niebezpieczeństwo lub szkoda powstały w czasie ruchu pojazdu; właściciel, posiadacz lub użytkownik, jeżeli interwencja na nieruchomości albo z powodu działania instalacji (urządzenia) była konieczna z uwagi na jej szczególny potencjał zagrożenia; użytkownik automatycznej instalacji zgłaszania pożarów, jeśli wywołała fałszywy alarm; osoba, która wbrew własnemu przekonaniu lub na skutek rażącej nieznajomości stanu faktycznego zaalarmowała straż pożarną; osoba, w której interesie postawiono wartę pożarniczą; gmina, której w ramach interwencji międzygminnej udzielono pomocy, jeżeli nie obowiązują lub nie zostaną zawarte inne porozumienia.

Gmina może ustalić w statucie, że do zwrotu kosztów z tytułu interwencji straży pożarnej wykraczającej poza zwalczanie pożaru może być zobowiązana: osoba, której zachowanie spowodowało konieczność interwencji, jak również 
osoby wymienione w $\S 4$ ust. 2 zd. 1 i ust. 3 ustawy policyjnej Saksonii ${ }^{25}$; ponadto właściciel rzeczy, której stan spowodował konieczność interwencji; osoba władająca rzeczywiście taką rzeczą; osoba, w której interesie nastąpiła interwencja. Większa liczba zobowiązanych odpowiada solidarnie. Ustawa przyjmuje jednak ogólne zastrzeżenie, że zwrotu kosztów nie należy żądać, jeśli będzie to stanowiło nadmierne obciążenie dla zobowiązanego.

\section{$\mathrm{V}$}

Można przyjąć, że system organizacji i funkcjonowania niemieckich ochotniczych straży pożarnych - istniejący, ale też modyfikowany od stu kilkudziesięciu lat — spełnia założone cele. W dyskusji nad przyszłością pożarnictwa w Niemczech wskazuje się jednak zagrożenie jego sprawnego funkcjonowania. Od kilkunastu lat w Niemczech zmniejsza się bowiem liczba strażaków ochotników. W 2000 roku było ich 1042 435, a w 2015 roku już tylko 996 628. Odpowiednio w 2000 roku istniało 24664 ochotniczych straży pożarnych, a w 2015 roku już tylko $22690^{26}$. Można zatem zauważyć tendencję spadkową. Rada gminy może wprawdzie w razie braku ochotników wprowadzić obowiązkowe uczestnictwo w straży pożarnej określonych osób spełniających kryteria zdrowotne i wiekowe, wskazuje się jednak, że nie rozwiązuje to problemu. Osoby kwalifikujące się do służby często są nieosiągalne w ciągu dnia, gdyż nie są aktywne zawodowo na obszarze działania straży i w związku z tym nie mogą dotrzymać dziesięciominutowego okresu zgłoszenia się do straży po ogłoszeniu alarmu.

Takie rozwiązanie, dotychczas unikane, w praktyce może okazać się nieskuteczne. Dlatego też w dyskusji nad koniecznymi zmianami w organizacji i funkcjonowaniu ochotniczych straży pożarnych w Niemczech w celu ich wzmocnienia kadrowego proponuje się uzupełniające zatrudnienie przez gminy strażaków zawodowych bądź częściową prywatyzację zadań ochotniczych straży pożarnych. Będzie to jednak wymagało dokonania zmian ustawowych.

25 Polizeigesetz des Freistaates Sachsen (SächsPolG). In der Fassung der Bekanntmachung vom 13. August 1999 (SächsGVB1, s. 466).

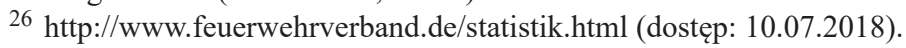




\section{Bibliografia}

Feuerwehr, [hasło w:] W.-D. Prendke, J. Bartetzko, B. Brutscher, R. Fischer, A. Fleck, H.-O. Geisel, J. Hahn, F. Kircher, J. Klein, J. Matenaer, W. Maurer, J. Rönnfeldt, E. Ortelt, H. Schröder,

R. Zimmermann, Lexikon der Feuerwehr, Kohlhammer 1999.

Fleck E., Turner standen an den Wiegen der freiwilligen Feuerwehren, [w:] H.-G. Kernmayr, Der goldene Helm, München 1956.

Knemeyer F.-L., Polizei- und Ordnungsrecht, München 1995.

Leupold D., Die freiwilligen Feuerwehren in der Rheinprovinz bis 1918, Köln 2003.

Richter P., Historische Rechtsgrundlagen für die Feuerwehren auf dem Gebiet des Landes Brandenburg, „Beiträge zur Feuerwehrgeschichte”, z. 4.

Wolter F., Die freiwilligen Feuerwehren in Österreich und Deutschland, Wiesbaden 2011.

\section{Wykaz aktów prawnych}

Gemeindeordnung für den Freistaat Sachsen (SächsGemO) vom 21. April 1993 (SächsGVBl, s. 301).

Gesetzes zur Neuordnung des Brandschutzes, Rettungsdienstes und Katastrophenschutzes im

Freistaat Sachsen. Vom 24. Juni 2004 (SächsGVB1, nr. 9, s. 245, 647).

Grundgesetz für die Bundesrepublik Deutschland vom 23. Mai 1949 (BGB1, s. 1).

Polizeigesetz des Freistaates Sachsen (SächsPolG), in der Fassung der Bekanntmachung vom 13.

August 1999 (SächsGVBl, s. 466).

\section{Źródła internetowe}

Deutscher Feuerwehrverband. Statistik, http://www.feuerwehrverband.de/statistik.html.

Jarausch D., Feuerwehren. Wie sind sie entschtanden?, https://www.vfdb.de/fileadmin/abdownloads/

Vortrag_CTIF-AG-Feuerwehrhistorik_10_2009_07_03_2009.doc.pdf.

https://de.wikipedia.org/wiki/Pflichtfeuerwehr.

https://de.wikipedia.org/wiki/Feuerwehrgesetz_(Deutschland).

http://deacademic.com/dic.nsf/dewiki/2462702.

http://www.feuerwehrverband.de/geschichte.html.

http://www.feuerwehrverband.de/ordentliche-mitglieder.html?\&L=0Sebastian.

https://www.cpe.gov.pl/aktualnosci/szczegoly/696,program-wspolpracy-interreg-polska-saksonia-

2014-2020-nowe-projekty-oraz-plan-naborow-w-2018-r.

http://www.feuerwehrverband.de/statistik.html.

\section{Inne źródła}

Berufsfeuerwehren in Deutschland - Komplettes Adressverzeichnis, Feuerwehr-Magazin, Ebner Verlag 2016.

Program Współpracy INTERREG Polska-Saksonia 2014-2020 — projekty i plan naborów w 2018 roku. 


\title{
The status of volunteer fire brigades in Germany
}

\author{
Summary
}

Volunteer fire brigades have existed in Germany since the mid-19th century. There are belong to the category of public fire brigades next to professional and mandatory fire brigades. They are performing public tasks of the community in the field of fire protection. They are also the basis for the system of this protection at the national level. They provide technical assistance in combating the effects of disasters, in the emergency service and in removing threats to the environment. They are based on the voluntary and social involvement of their members, and only partly on full-time professionals.

Keywords: protection against disasters, emergency service, public fire brigade, private volunteer fire brigade, professional fire service, mandatory fire brigade. 